\title{
MODEL SPLINE KUADRATIK UNTUK MERANCANG KURVA PERTUMBUHAN BALITA DI KOTA PADANG
}

\author{
DIAN YOSEFANNY, HAZMIRA YOZZA, IZZATI RAHMI H.G \\ Jurusan Matematika, \\ Fakultas Matematika dan Ilmu Pengetahuan Alam, Universitas Andalas, \\ Kampus UNAND Limau Manis Padang, Indonesia, \\ dian_yosefanny@yahoo.com
}

\begin{abstract}
Abstrak. Pertumbuhan balita merupakan suatu proses pertambahan ukuran, baik volume, bobot dan jumlah sel yang bersifat irreversible. Pertumbuhan dan perkembangan balita suatu hal yang perlu mendapat perhatian besar, biasanya dikenal dengan istilah golden age. Oleh karena itu, pertumbuhan balita harus dilakukan pemantauan dengan mengukur berat badan setiap bulannya. Pemantauan pertumbuhan balita biasanya mengacu pada suatu kurva pertumbuhan. Untuk merancang kurva pertumbuhan balita di Kota Padang yaitu dengan pendekatan spline kuadratik. Pemilihan model terbaik yaitu dengan cara pemilihan banyak serta nilai titik knot berdasarkan nilai GCV yang minimum. Dari analisis regresi spline kuadratik diketahui bahwa perubahan pola pertumbuhan balita di Kota Padang terjadi pada umur 3 bulan, 10 bulan dan 15 bulan pertama. Sehingga diperoleh model regresi spline kuadratik dengan model dugaan:

$$
\begin{aligned}
\widehat{y}_{i}= & 3,251+1,724 x_{i}-0,2477 x_{i}^{2}+0,2773\left(x_{i}-3\right)_{+}^{2}-0,0690\left(x_{i}-10\right)_{+}^{2} \\
& +0,0382\left(x_{i}-15\right)_{+}^{2}+\varepsilon .
\end{aligned}
$$
\end{abstract}

Kata Kunci: Pertumbuhan Balita, Regresi Spline Kuadratik, GCV

\section{Pendahuluan}

Pertumbuhan pada balita adalah suatu proses pertambahan ukuran, baik vo-lume, bobot dan jumlah sel yang bersifat irreversible (tidak dapat kembali ke asal). Pertumbuhan dan perkembangan balita merupakan suatu hal yang perlu mendapat perhatian besar karena masa balita merupakan masa dengan pertumbuhan yang sangat pesat dan kritis, biasanya dikenal dengan istilah golden age. Pertumbuhan balita pada masa ini merupakan suatu parameter sederhana untuk menilai normal tidaknya status kesehatan anak.

Pemantauan pertumbuhan balita biasanya mengacu pada suatu kurva pertumbuhan. Kurva ini adalah salah satu alat untuk menilai atau mengevaluasi apakah pertumbuhan anak sudah baik atau tidak. Kurva pertumbuhan yang biasa digunakan di Indonesia dikenal dengan Kartu Menuju Sehat (KMS). KMS memuat kurva pertumbuhan normal anak berdasarkan indeks antropometri berat badan menurut umur. KMS ini disusun berdasarkan tabel baku rujukan WHO/NCHS.

Dalam penelitiannya mengenai KMS [1], menyimpulkan bahwa penggunaan KMS yang merupakan standar baku dari WHO yang dikeluarkan oleh NCHS (National Center Health Statistics) kurang menggambarkan perilaku pertumbuhan 
balita yang ada di Indonesia. Sehingga yang menarik untuk diketahui apakah penelitian [1] juga sesuai dengan pertumbuhan balita di Kota Padang. Oleh karena itu, perlu dilakukan suatu penelitian untuk mendapatkan gambaran awal mengenai pertumbuhan balita di Kota Padang.

Secara umum pola pertumbuhan balita cenderung memiliki perubahan perilaku pada umur-umur tertentu, sehingga pemodelan dengan regresi spline adalah metode yang sesuai untuk melihat dan memantau pola pertumbuhan balita. Pada penelitian ini akan diterapkan metode spline kuadratik untuk merancang kurva pertumbuhan balita di kota Padang berdasarkan berat badan menurut umur balita.

\section{Landasan Teori}

\subsection{Pertumbuhan Balita}

Pertumbuhan (growth) adalah perubahan dalam besar, jumlah, ukuran atau dimensi tingkat sel, organ maupun individu, yang biasa diukur dengan ukuran berat (gram, pound, kilogram), ukuran panjang (cm, meter), umur tulang dan keseimbangan metabolik (retensi kalsium dan nitrogen tubuh) [6].

Dalam praktek keseharian, pemantauan pertumbuhan dilakukan dengan mengukur berat badan, tinggi badan dan lingkar kepala. Kurva pertumbuhan diperlukan sebagai acuan standar pertumbuhan yang normal. Setiap negara mempunyai kurva pertumbuhan sendiri yang digunakan sebagai acuan. Di Indonesia, Ikatan Dokter Anak Indonesia (IDAI) merekomendasikan penggunaan kurva WHO untuk anak umur $0-5$ tahun. Frekuensi pengukuran yang disarankan adalah umur 3 bulan sampai dengan 2 tahun setiap 3 bulan dan umur 2 sampai 6 tahun setiap 6 bulan $[2]$.

\subsection{Pengujian Signifikasi Parameter}

\subsubsection{Pengujian Secara Serempak (Simultan) dengan Uji F}

Pada tahap ini dilakukan pengujian terhadap semua koefisien regresi secara serempak (simultan). Pada dasarnya, pengujian ini dilakukan untuk menguji apakah terdapat hubungan linier antara peubah tak bebas dengan suatu peubah bebas $X_{1}, X_{2}, \cdots, X_{k}$ Hipotesis [5]:

$$
\begin{aligned}
& H_{0}: \beta_{1}=\beta_{2}=\cdots=\beta_{k}=0, \\
& H_{1}: \text { Ada } \beta_{j} \neq 0 .
\end{aligned}
$$

Statistik uji:

$$
F_{\text {hit }}=\frac{K T R}{K T S}=\frac{J K R / k}{J K S /(n-k-1)}
$$

Daerah penolakan tolak $H_{0}$ jika $F_{h i t}>F_{(\alpha, k, n-k-1)}$ atau jika nilai-sig $<\alpha(\alpha$ adalah taraf uji yang digunakan) dan disimpulkan bahwa terdapat peubah bebas yang berpengaruh terhadap peubah terikat, Jika sebaliknya, disimpulkan bahwa 


\begin{tabular}{|c|c|c|c|c|}
\hline sumber keragaman & Derajat bebas & Jumlah Kuadrat & Kuadrat tengah & $F_{\text {hit }}$ \\
\hline Regresi & $d b r=k$ & JKR & KTR $=\frac{J K R}{d b r}$ & $F_{h i t}=\frac{K T R}{K T S}$ \\
\hline Sisaan & $d b s=n-k-1$ & JKS & KTS $=\frac{J K S}{d b s}$ & \\
\hline Total & $d b t=n-1$ & JKT & & \\
\hline
\end{tabular}

Tabel 1. [5] Analisis Ragam

tidak satupun peubah bebas yang berpengaruh terhadap peubah terikat, dimana :

$$
\begin{aligned}
& J K R=\mathbf{b}^{T} \mathbf{X}^{T} \mathbf{Y}-n \bar{y}^{2}, \\
& J K S=\mathbf{Y}^{T} \mathbf{Y}-\mathbf{b}^{T} \mathbf{X}^{T} \mathbf{Y}, \\
& J K T=\mathbf{Y}^{T} \mathbf{Y}-n \bar{y}^{2} .
\end{aligned}
$$

\subsubsection{Pengujian Secara Individu (Parsial) dengan Uji $t$}

Jika pada pengujian secara serempak diputuskan untuk tolak $H_{0}$, maka disimpulkan bahwa paling tidak satu peubah bebas memiliki kontribusi nyata terhadap model. Untuk itu, pada tahap selanjutnya perlu dilakukan pengujian terhadap masing-masing peubah bebas secara individu.

Hipotesis :

$$
\begin{aligned}
& H_{0}: \beta_{j}=0, \\
& H_{1}: \beta_{j} \neq 0 .
\end{aligned}
$$

Statistik uji:

$$
t=\frac{b_{j}}{S E\left(b_{j}\right)},
$$

dimana $S E\left(b_{j}\right)=\sqrt{c_{j j} s^{2}}$ dan $s^{2}=K T S$ adalah penduga bagi $\sigma^{2}$.

$H_{0}$ akan ditolak jika $\left|t_{\text {hitung }}\right|>t_{\left(\frac{\alpha}{2}, n-k-1\right)}$ atau jika nilai-sig $<\alpha(\alpha$ adalah taraf uji) dan disimpulkan bahwa peubah $X_{j}$ berpengaruh terhadap $Y$; selainnya, peubah $X_{j}$ tidak berpengaruh terhadap $Y[5]$.

\subsection{Regresi Nonparametrik}

Metode regresi nonparametrik merupakan metode pendekatan regresi yang digunakan ketika tidak terdapat informasi yang lengkap tentang bentuk pola data atau ketika kurva regresi antara peubah bebas (independent) dengan peubah tak bebas (dependent) tidak diketahui bentuk atau polanya. Secara umum model regresi nonparametrik dapat dinyatakan sebagai berikut [3] :

$$
y_{i}=f\left(x_{i}\right)+\varepsilon_{i} ; \quad i=1,2,3, \cdots, n,
$$

dengan $\varepsilon_{i}$ adalah error ke- $i$ yang diasumsikan berdistribusi $\mathrm{N}\left(0, \sigma^{2}\right)$, dan $\mathrm{f}\left(x_{i}\right)$ adalah fungsi regresi yang tidak diketahui bentuk atau polanya. 


\subsection{Spline dalam Regresi Nonparametrik}

Spline merupakan model polinom yang memiliki sifat tersegmen atau terpotongpotong yang terbentuk pada setiap titik knot dan dapat menghasilkan fungsi regresi yang sesuai dengan data [3]. Fungsi spline berorde $\mathrm{m}$ dengan titik-titik knot $K_{1}, K_{2}, \cdots, K_{N}$. Didefinisikan sebagai sembarang fungsi f yang disajikan dalam bentuk [4] :

$$
f_{(x)}=\sum_{j=1}^{m} \beta_{j} x_{i}^{j}+\sum_{k=1}^{N} \beta_{m+k}\left(x_{i}-K_{k}\right)_{+}^{m}
$$

dengan

$$
\left(x_{i}-K_{k}\right)_{+}^{m}= \begin{cases}\left(x_{i}-K_{k}\right)^{m} & , x \geq K_{k} \\ 0 & , x<K_{k} .\end{cases}
$$

\subsection{Pemilihan Model Regresi Nonparametrik Spline dengan Pemulus ( $\lambda$ ) yang Optimal}

Pemilihan $\lambda$ optimal dalam regresi nonparametrik spline pada hakekatnya merupakan pemilihan lokasi titik knot. Pemilihan knot pada penelitian ini dilakukan secara trial error atau uji coba. Salah satu metode pemilihan parameter pemulus yang banyak dikembangkan adalah Generalized Cross Validation (GCV). Pada model spline kuadratik kriteria GCV didefinisikan sebagai berikut:

$$
G C V(\lambda)=\frac{M S E(\lambda)}{\left[n^{-1} \operatorname{tr}(I-A(\lambda))\right]^{2}}
$$

dengan

$$
\begin{aligned}
\mathbf{A} & =\mathbf{X}\left(\mathbf{X}^{\prime} \mathbf{X}\right)^{-1} \mathbf{X}^{\prime}, \\
M S E(\lambda) & =n^{-1} \sum_{i=1}^{n}\left(y_{i}-f_{\lambda}\left(x_{i}\right)\right)^{2} .
\end{aligned}
$$

Kriteria $\operatorname{GCV}(\lambda)$ diharapkan memiliki nilai yang minimum, sehingga model regresi nonparametrik spline dapat dikatakan memiliki $\lambda$ yang optimal.

\subsection{Estimasi Selang Kepercayaan Nilai Tengah Respon}

Selang kepercayaan dari rata-rata variabel tak bebas pada titik tertentu, seperti $x_{11}, x_{12}, \cdots, x_{1 k}$. Vektor $x_{i}$ dapat didefinisikan sebagai [5]:

$$
X_{(k+1) * 1}=\left[\begin{array}{c}
1 \\
x_{11} \\
x_{12} \\
\vdots \\
x_{1 k}
\end{array}\right],
$$

nilai yang tepat pada titik $x_{11}, x_{12}, \cdots, x_{1 k}$ dapat dinyatakan sebagai :

$$
\widehat{y_{i}}=x_{i}^{T} \cdot \widehat{\beta}
$$


Oleh karena itu, selang kepercayaan (1- $\alpha) 100 \%$ dari rata-rata variabel tak bebas di titik $x_{11}, x_{12}, \cdots, x_{1 k}$ adalah:

$$
\widehat{y}_{i}-t_{\left(\frac{\alpha}{2}, n-p\right)} \sqrt{\widehat{\sigma}^{2} x_{i}^{T}\left(X^{T} X\right)^{-1} x_{i}} \leq y_{i} \leq \widehat{y}_{i}+t_{\left(\frac{\alpha}{2}, n-p\right)} \sqrt{\widehat{\sigma}^{2} x_{i}^{T}\left(X^{T} X\right)^{-1} x_{i}}
$$

\section{Pembahasan}

\subsection{Data}

Data yang digunakan dalam panelitian ini adalah data sekunder yang diperoleh dari penelitian Izzati Rahmi H.G dkk. Variabel bebas (x) yang digunakan adalah umur balita (dalam bulan) dan variabel tak bebas (y) yaitu berat badan balita (dalam kilogram). Banyak data yang digunakan pada penelitian ini adalah 510 pengamatan.

\subsection{Langkah-langkah}

Langkah-langkah analisisnya sebagai berikut:

(1) Membuat deskriptif data antara umur balita (x) dengan berat badan balita (y).

(2) Memodelkan variabel bebas dan tak bebas dengan menggunakan regresi nonparametrik spline kuadratik dengan beberapa kombinasi banyak dan lokasi titik knot.

(3) Pemilihan titk knot optimal menggunakan GCV yang minimum.

(4) Membuat persamaan regresi nonparametrik spline kuadratik berdasarkan pemilihan titik knot yang optimal.

(5) Membuat kurva estimasi regresi spline kuadratik.

(6) Menguji signifikan parameter regresi nonparametrik spline kuadratik secara serentak (Uji-F) dan Individu (Uji-t).

(7) Merancang kurva pertumbuhan dengan pendekatan selang kepercayaan terhadap nilai regresi spline kuadratik.

\subsection{Penyelesaian}

\subsubsection{Deskriptif Data}

Data yang digunakan pada penelitian ini adalah data berat badan balita di kota Padang dari umur 0 bulan sampai umur 60 bulan. Selanjutnya akan dilihat pola sebaran data antara peubah tak bebas (berat badan balita) dan peubah bebas (umur balita) dengan menggunakan diagram pencar yang ditampilkan pada Gambar 1.

Dapat dilihat bahwa pada Gambar 1 pola data hubungan berat badan balita (Kg) dengan umur balita (bulan) mempunyai variasi yang berbeda untuk setiap golongan umur. Karena variasi pertumbuhan balita di kota Padang sangat tinggi, dan bentuk pola pada peubah bebas dengan peubah tak bebas tidak terdapat informasi yang lengkap terhadap kurva regresi maka peneliti tertarik untuk merancang kurva pertumbuhan balita dengan pendekatan regresi nonparametrik spline yang harus mampu mewakili variasi berat badan balita di kota Padang. Untuk mengetahui pola pertumbuhan balita di kota Padang, maka digunakan nilai persentil 50 


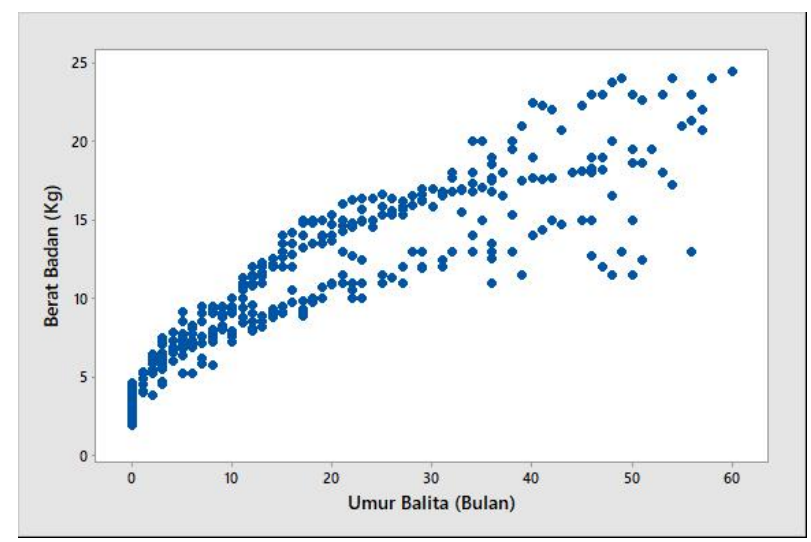

Gambar 1. Diagram Pencar Umur Balita (Bulan) terhadap Berat Badan Balita (Kg)

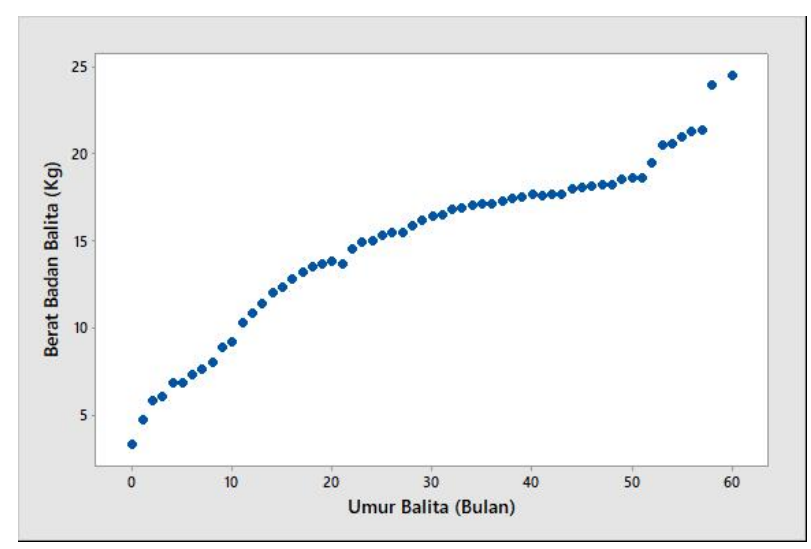

Gambar 2. Scatterplot nilai median berat badan balita di Kota Padang

(median), berikut adalah scatterplot persentil 50 antara berat badan $(\mathrm{Kg})$ terhadap umur (bulan) balita.

Pada Gambar 2 penggunaan nilai persentil 50 (median) ini karena pola pada kurva yang tidak mulus atau terdapat pencilan sehingga penggunaan nilai median diharapkan tidak terpengaruh oleh data pencilan tersebut. Selain itu, nilai persentil 50 (median) merupakan salah satu nilai yang digunakan dalam standar baku NCHS untuk menggambarkan kurva pertumbuhan yang nantinya akan menjadi garis pusat rancangan kurva pertumbuhan.

Berdasarkan pada Gambar 2 terlihat bahwa berat badan balita (Kg) terhadap umur balita (Bulan) tidak bisa didekati dengan satu garis regresi saja tetapi pendekatan yang lebih baik adalah dengan membagi umur menjadi beberapa segmen dan dibentuk model regresi untuk setiap segmen. 


\subsubsection{Model Regresi Nonparametrik}

Berdasarkan bentuk kurva pertumbuhan berat badan balita di kota Padang, maka berikut disajikan dua model regresi spline untuk 1 titik knot, 2 titik knot dan 3 titik knot dengan nilai GCV minimum.

\begin{tabular}{|c|c|c|c|}
\hline Model Spline & 1 titik knot & 2 titik knot & 3 titik knot \\
\hline Orde 1 & $K_{1}=15$ & $K_{1}=2 K_{2}=17$ & $K_{1}=2 K_{2}=10 K_{3}=15$ \\
(Spline Linier) & $\mathrm{GCV}=3,3297$ & $\mathrm{GCV}=3,2236$ & $\mathrm{GCV}=3,2351$ \\
\hline Orde 2 & $K_{1}=2$ & $K_{1}=2 K_{2}=20$ & $K_{1}=3 K_{2}=10 K_{3}=15$ \\
(Spline Kuadratik) & $\mathrm{GCV}=3,5626$ & $\mathrm{GCV}=3,2813$ & $\mathrm{GCV}=3,2216$ \\
\hline
\end{tabular}

Tabel 2. Kombinasi Ordo dengan 1 titik knot, 2 titik knot, dan 3 titik knot

Pada Tabel 2 diperoleh GCV yang minimum terdapat pada model spline kuadratik, dengan kombinasi tiga titik knot, yaitu knot ke-3, ke-10 dan ke-15 dengan nilai GCV sebesar 3,2216.

Berikut adalah model spline kuadratik dengan tiga kombinasi titik knot yaitu $K_{1}=3, K_{2}=10$ dan $K_{3}=15$.

$$
\widehat{y_{i}}=b_{0}+b_{1} x_{i}+b_{2} x_{i}^{2}+b_{3}\left(x_{i}-3\right)_{+}^{2}+b_{4}\left(x_{i}-10\right)_{+}^{2}+b_{5}\left(x_{i}-15\right)_{+}^{2}+\varepsilon .
$$

Terdapat empat model regresi spline kuadratik untuk masing-masing potongan atau segmen. Berikut adalah scatterplot model regresi spline kuadratik dengan kombinasi tiga titik $\operatorname{knot} K_{1}=3, K_{2}=10$ dan $K_{3}=15$.

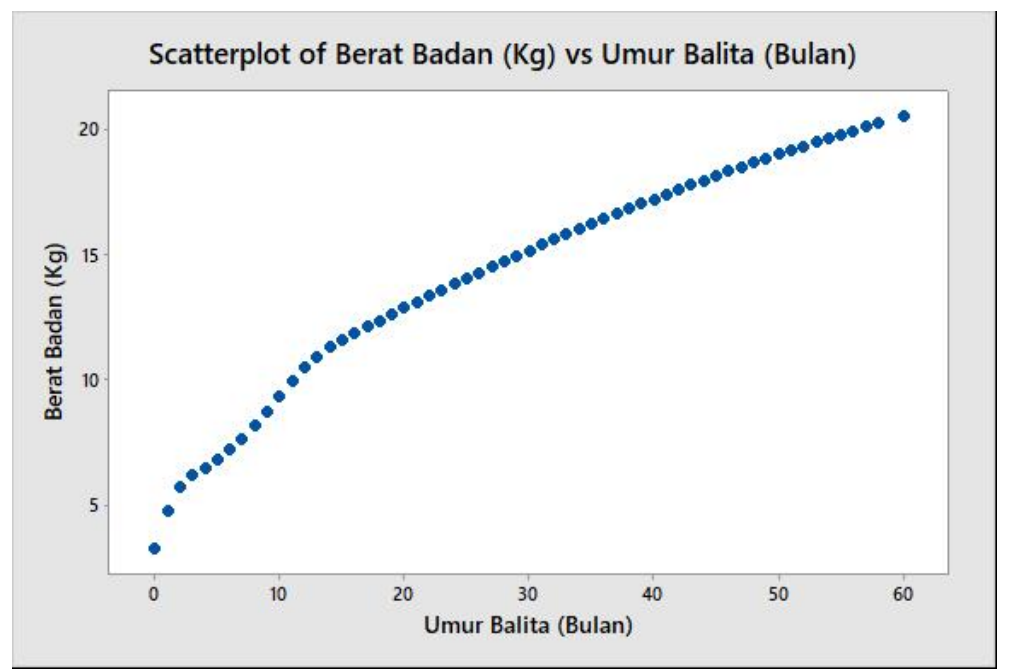

Gambar 3. Scatterplot spline kuadratik dengan titik knot $K_{1}=3, K_{2}=10$ dan $K_{3}=15$ 


\subsubsection{Pengujian Signifikan Parameter Model Regresi Spline Kuadratik}

Uji signifikan parameter digunakan untuk mengetahui apakah sebuah peubah bebas berkontribusi nyata terhadap model. Terdapat dua pengujian signifikan para-meter, yaitu pengujian secara serempak (Uji-F) dan pengujian secara individu (uji-t).

(1) Uji Serempak.

Untuk mengetahui pengaruh parameter secara serempak terhadap model yang telah dibangun maka dilakukan uji- $F$.

Hipotesis :

$$
\begin{aligned}
& H_{0}: b_{1}=b_{2}=\cdots=b_{5}=0, \\
& H_{1}: \text { Ada } b_{j} \neq 0 .
\end{aligned}
$$

Berdasarkan uji hipotesis dengan taraf nyata 0,05 diketahui bahwa $P_{\text {value }}<$ 0,05 sehingga diputuskan tolak $H_{0}$ yang berarti secara serempak parameter signifikan terhadap model yang telah dibangun.

(2) Uji Individu.

Setelah dilakukan uji signifikan secara serentak maka selanjutnya adalah dilakukan pengujian parameter secara individu untuk menentukan variabelvariabel bebas yang signifikan terhadap $y$.

Hipotesis :

$$
\begin{aligned}
& H_{0}: b_{j}=0, \\
& H_{1}: b_{j} \neq 0, j=1,2,3,4,5 .
\end{aligned}
$$

Berdasarkan uji hipotesis secara individu hasil pengujian parameter model spline kuadratik deng tiga kombinasi titik knot secara individu diperoleh kesimpulan tolak $H_{0}$ pada setiap parameter. Hal ini dapat diketahui karena nilai $P_{\text {value }}<\alpha$. Artinya semua parameter secara individu signifikan terhadap model yang telah dibangun.

\subsubsection{Rancangan Kurva Pertumbuhan Balita di Kota Padang}

Rancangan kurva pertumbuhan balita dapat didekati dengan model spline kuadratik. Pada Gambar 4 diberikan plot persebaran model spline kuadratik dengan umur balita (bulan).

Pada Gambar 4 dapat dilihat secara visual bahwa pola pertumbuhan balita naik secara kritis pada umur 0 sampai 3 bulan, pada umur 3 bulan sampai 10 bulan kenaikan berat badan balita mulai melambat, dan diatas umur 15 bulan pertumbuhan berat badan balita meningkat tetapi meningkat secara melambat. Oleh karena itu akan dibangun selang kepercayaan dari plot model spline kuadratik yaitu untuk satu kali standar deviasi, dua kali standar deviasi, dan tiga kali standar deviasi atau berturut-turut selang kepercayaan 68,268\%, 95,45\%, dan 99,73\%.

Pada Gambar 5 diberikan plot berat badan balita untuk setiap selang kepercayaan. Pada Gambar 5 ditunjukkan bahwa semakin meningkatnya umur balita maka semakin lebar selang kepercayaan pada berat badan balita. Garis selang kepercayaan yang terbentuk yaitu 68,268\%, 95,45\% dan 99,73\%. 


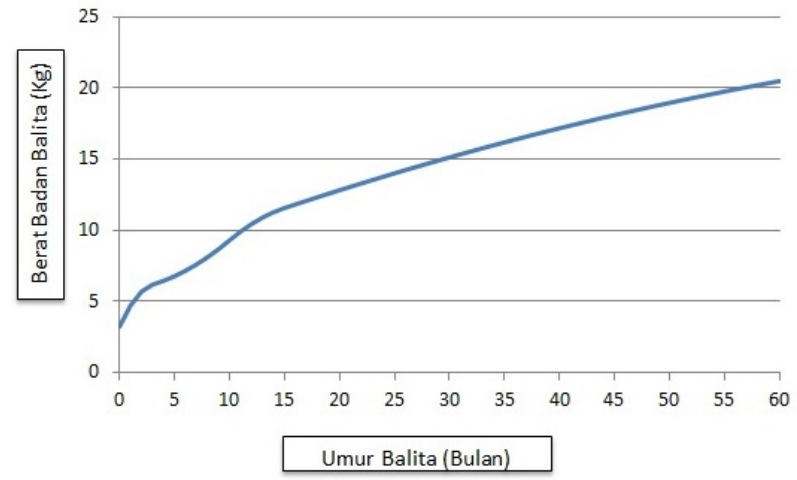

Gambar 4. Plot berat badan balita untuk setiap nilai dugaan

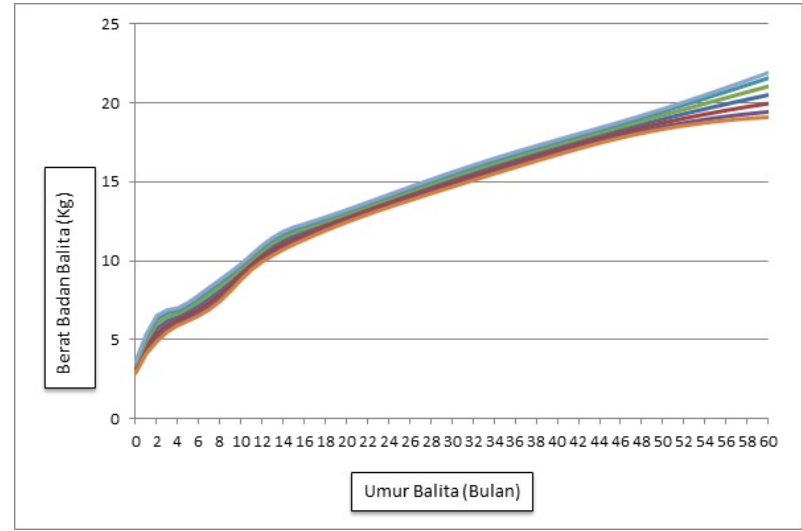

Gambar 5. Plot berat badan balita untuk setiap selang kepercayaan

Garis selang kepercayaan 68,268\% dibentuk dari:

$$
\widehat{y} \pm \sqrt{\widehat{\sigma^{2}} x_{i}^{T}\left(X^{T} X\right)^{-1} x_{i}}
$$

Garis selang kepercayaan 95,45\% dibentuk dari:

$$
\widehat{y} \pm 2 \sqrt{\widehat{\sigma^{2}} x_{i}^{T}\left(X^{T} X\right)^{-1} x_{i}} .
$$

Garis selang kepercayaan 99,73\% dibentuk dari:

$$
\widehat{y} \pm 3 \sqrt{\widehat{\sigma^{2}} x_{i}^{T}\left(X^{T} X\right)^{-1} x_{i}} .
$$

\section{Daftar Pustaka}

[1] Budiantara, I.N. 2009. Spline dalam Regresi Nonparametrik dan Semiparametrik: Sebuah Pemodelan Statistika Masa Kini dan Masa Mendatang. Pidato pengukuhan untuk jabatan guru besar dalam bidang Matematika Statistika dan Probabilitas, Jurusan Statistika FMIPA, ITS, Surabaya. 
[2] Depkes RI. 1997. Buku Kehatan Ibu dan Anak. Jakarta: Kementrian Kesehatan dan JICA.

[3] Eubank R. 1999. Spline Smoothing and Nonparametric Regression. Marcel Dekker, New York.

[4] Eubank, R.L. 1988. Nonparametric Regression And Spline Smoothing. New York: Marcel Dekker,Inc.

[5] Montgomery dan Peck. 1992. Introduction To Linier Regression Analysis, 2nd edition. John Willey dan Sons, INC.

[6] Soetjiningsih. 1995. Tumbuh Kembang Anak. Jakarta: EGC. 